\title{
3 Unlocking the door of the city hall
}

\section{Vienna's participatory shift in urban development policy}

\author{
Byeongsun Ahn and Elisabetta Mocca
}

\section{Introduction}

Participation is the holy grail of recent policy-making and has drawn significant academic attention. Indeed, progressive policy-makers, as well as political scholars, seem to agree upon the need to involve citizens in public affairs to expand democracy. However, as Arnstein (1969) already noted in the late 1960s, there may be different degrees of participation, from tokenism to citizen power. In practice, the topdown form of participation commonly allowed by public actors may or may not consist of emancipatory mechanisms that enable a mutual partnership between citizens and powerholders in decision-making and policy design.

In recent years, urban researchers have thrown light on participatory mechanisms rolled out in various cities across the world, ranging from Latin America (Goldfrank, 2007) to the United States and the United Kingdom (Elwood, 2004), and from continental Europe (Garcia, 2006) to China (Zhang et al., 2020). Among them, citizen participation in Vienna has been studied vis-à-vis communitarian urban development policies (for its historical evolution, see Suitner, 2020). Extant research has noted how participatory policies have been implemented in a context dominated by the long-lasting legacy of a vertical policy-making style harking back to Red Vienna and consolidated in the post-war period (Novy and Hammer, 2007). Notwithstanding some changes in the political landscape in recent years (for the erosion of the Social-Democrats' electoral base, see Chapter 2 by Mocca and Friesenecker in this volume), the City of Vienna has often been described as a 'Weberian-style administration' (Kornberger, et al., 2017, p. 180), characterised by a 'corporatist' (Novy et al., 2001, p. 131), 'topdown' (Novy and Hammer, 2007, p. 213) governing system. Moreover, it has been observed that endeavours to make Viennese policy-making 
more inclusive have been hindered by looming clientelism (Dangeschat and Hamedinger, 2009).

Consequently, non-tokenistic involvement of citizens in decisionmaking appears to find little room in the Viennese policy-making and deliberative process. In effect, much of the decision-making in urban development has often been centrally designed and implemented, with little delegated power to non-public actors for community control. Nevertheless, following international trends towards greater involvement of citizens in public affairs, some inroads into Vienna's interventionist and vertical policy approach have been made. Since the 1970s, the city government gradually introduced mechanisms to draw citizens into policy design and deliberation, especially in small-scale planning. Whilst such citizen involvement has been expanded through the development of the Vienna Model over the decades that followed, some obstacles to full representation of local interests in non-electoral participation still persist, as discussed in the ensuing sections.

This chapter highlights the political dimension of urban justice in Vienna, which cannot be reduced to resource maldistribution or misrecognition of residents' status - examined elsewhere in this volume. Therefore, the analysis presented here builds on Fraser's threedimensional theory of justice, 'incorporating the political dimension of representation, alongside the economic dimension of distribution and the cultural dimension of recognition' (Fraser, 2010, p. 15). The extent of representation, as a precondition for the other two dimensions of distribution and recognition (for access to labour welfare, see Chapter 6 by Ahn and Kazepov; for access to housing, see Chapter 4 by Litschauer and Friesenecker), entails strong power implications. In this regard, the degree to which public actors open the policy-making process up to civil society, including less privileged residents, determines the policy outcomes. Therefore, the historical trajectory of Vienna's participatory mechanisms begs the question as to how this particular path has developed over time, which social groups benefit from this path, and which policy instruments have been deployed to foster or prevent the mainstreaming of citizen participation in the City's policy-making process.

\section{The historical pathway towards the Vienna Model}

Prompted by the suburbanisation of the inner-city districts, a new planning paradigm emerged in Vienna in the 1970s. The City moved away from the functionalist planning model of the previous decade, which had focused on car-centric urban expansion (Feuerstein and 
Fitz, 2009). In this new era, the city government set the renewal of the dilapidated inner-city districts (between the outer ring-road and the 1st district) as a key task, where poor quality residential buildings required refurbishment interventions. A shift also emerged in response to growing public opposition to some of the large-scale development projects that were initiated throughout this period. The latter led to the demolition of the city's historical landmarks, such as Florianikirche (1965) and the Otto-Wagner Pavilion in the 12th district (1969), to make room for high-rise- and highway constructions in the central areas of the city. Between the late 1960s and the early 1970s, bottom-up initiatives against the functionalist urban projects, such as a new residential construction in a former red-light quarter (Spittelberg) in the seventh district, sparked debates on the restructuring of the City's planning system. The lack of citizen participation prior to that point in the planning process and the absence of an effective management structure in urban development were problematised within such discussions (Feuerstein and Fitz, 2009). In response, the city government began to deploy new participatory instruments to broaden resident involvement in urban renewal projects, where tenants and property owners became incorporated into the planning process. Subsequently, the institutionalisation of participatory planning then came about, building upon the legal amendments that followed this participatory turn, for example, the Vienna Building Code, the Old City Protection Act in 1972, and the Urban Renewal Act in 1974. This aimed not only to make locally specific problems more accessible to the planning authorities but also to reverse the declining public trust in the City's urban development strategies (Berger, 1984). Such changes laid the foundations for the City's new planning system where, on the one hand, active participation and engagement curbed potential conflicts between different residential groups. On the other hand, it provided a strong regulatory framework - complementing its housing policy and mitigated negative spillovers of housing and urban development (for the recent development of Vienna's housing and tenancy regulatory system, see Chapter 4 by Litschauer and Friesenecker).

At the same time, a momentum for greater citizen participation initiated a process of innovation in the City's planning management approach, which introduced a new collaborative arrangement in largescale development projects. Contrary to the expert-led technocratic approaches in the previous planning model, the new mode of governance enabled deliberation and the participation of a diverse range of both institutional and non-institutional actors, mediated by a decentralised control office. This method, referred to as the 'Vienna Model' 
(Freisitzer and Maurer, 1985), formalised an institutional space for public-private-citizen partnership, based on horizontal cooperation between planning groups and public administration. Whilst citizens' participation mainly still occurred in the form of information dissemination in the planning process, reforms in the late 1980s began to adopt an entrepreneurial approach to urban development. Market elements, such as competitive tendering, were incorporated into the City's new planning paradigm. In contrast to the 1980s' New Public Management reforms in the Anglo-American sphere, however, the rescaling process in Vienna retained a corporative network with a strong level of interdependency, beyond strictly contractual relations between institutional and non-institutional actors. This differed greatly from, for example, the urban policies adopted during the same period in Labour-led British cities, such as Barnsley, Rotherham and Liverpool, whose leaders began to embrace market-led regeneration in response to the defeat of the miners' strike in the mid-1980s, economic decline in working-class areas, and growing support for Thatcher's central government in their constituencies (Davies, 2004). Similarly, in light of shrinking federal public expenditure, from the late 1970s onwards (especially during Reagan's administration), American cities relied on the taxation of private businesses located in their areas to subsidise urban regeneration (Teaford, 2000). Unlike these examples, a strong presence of zoning and land-use regulations in Vienna mitigated the dominance of private market actors, whose participation in urban development was - and still is - controlled by a socially oriented selection procedure, involving all relevant municipal departments (see Chapter 4 by Litschauer and Friesenecker).

The restructuring of the planning system was simultaneously accompanied by the decentralisation of the city administration and the expansion of direct democracy. After a redevelopment plan of a large green space (Sternwartepark) was rejected in the first-ever city-level opinion poll in 1973, a number of reforms enhancing direct democracy were introduced under the newly nominated Social-Democratic (SPÖ) mayor, Leopold Gratz. Further, the SPÖ-led city council institutionalised different instruments of direct democracy, although the extent of citizens' influence in municipal policy-making was limited by its non-binding nature, as well as restrictive quorum and turnout rules (Pleschberger and Mertens, 2012). As a result, direct democracy in Vienna mainly occurred as an outcome of inter-party competition within the city council, employed to either approve or object to urban development proposals by the Social-Democrats in power or their opposition, the Christian-Democrats (ÖVP). Direct democracy equated to 
the use of opinion poll (Volksbefragung), mostly employed as a means of seeking popular support for policy implementation. However, its non-binding nature allowed political parties to pursue their urban development plans regardless of the outcome. This was true especially in the 1980s, as in the case of the Austria Centre Vienna ${ }^{1}$ (1981), which were subject to criticism by opposition parties and citizens' initiatives (Pleschberger and Mertens, 2012). With the decentralisation process in the late 1980s, a new mode of direct citizen participation was introduced at the district level, which expanded the right of codetermination of the local population within the districts' sphere of competence. Notwithstanding the expansion of participatory platforms, especially for non-institutional experts, the extent of direct citizen participation in this period was still dominated by tokenistic involvement in largescale urban development, mostly occurring in the form of information dissemination. Emerging participatory opportunities tended to be delegated to decentralised institutions, such as the Urban Renewal Offices (since 1974), often as an ad hoc reaction to grassroots discontent (e.g. Planquadrate, 1974-1979). Such bodies were not endowed with sufficient institutional competence and financial autonomy (Förster, 1988). In the years that followed, a more communitarian approach to direct citizen participation began to be incrementally incorporated. As we will see, however, the field and reach of its application remained constrained.

\section{New approaches to participation starting from the 1990s}

A new phase of participatory urban governance began in the early 1990s, as emerging urban challenges necessitated a reorientation of the planning strategies set in the previous decade. In light of the growing demand for economic competitiveness, place-branding strategies came to the fore in the City's urban policy priorities (Mayerhofer and Wolfmayr-Schnitzer, 1996). This shift occurred whilst maintaining the core concept of the Vienna Model: a mix of urban renewal and expansion strategies incorporated economic growth as one of the major policy objectives to enhance its cultural, technological, and economic attractiveness in the growing competition between cities (Mattl, 2000). One such example was the EXPO-Project, which was planned to expand the United Nations complex into an international congress quarter and develop a new urban centre near the Danube after a twin-city World's Fair with Budapest in 1995. As public worries grew concerning real estate speculation, tax burden and other issues, the right-wing Freedom Party (FPÖ) started a referendum petition in opposition to 
the twin-city World's Fair (Schimak, 1993). In response, an opinion poll was launched in 1991 by the SPÖ and the ÖVP, who were looking for popular support for the project, though it was ultimately rejected by the voters. This political failure of the two major parties marked the beginning of a phase of reorganisation in the participatory tools in urban planning. In contrast to outcome-oriented, one-way consultations, there arose a need to sustain public engagement in small-scale urban development, by which the local population could be incorporated into the entire planning process through a diverse range of participatory opportunities (Antalovsky and König, 1994). Accordingly, smaller working groups, consisting of public institutions, experts and residents, were formed through localised planning projects, where strategic planning concepts could be co-produced following multiple rounds of extensive information gathering and public discussions. This was accompanied by the further restructuring of the city

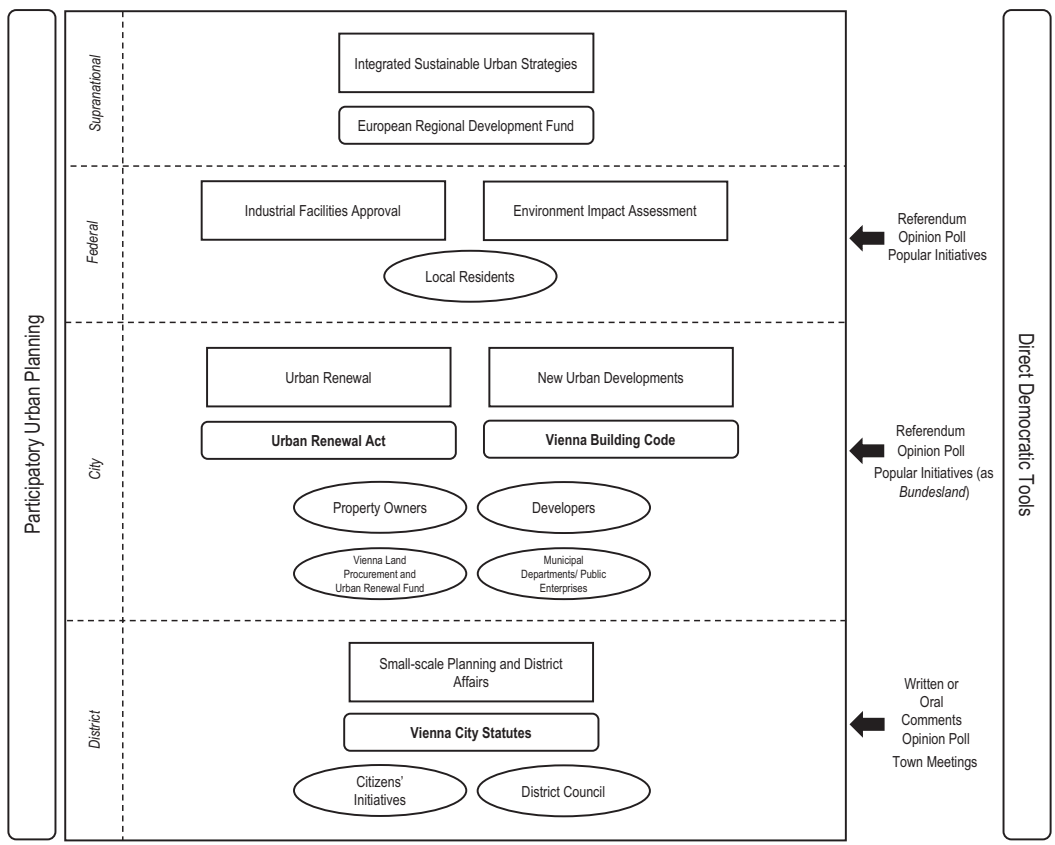

Figure 3.1 Institutional pathways to formal participation in urban development in Vienna.

Source: European Commission (2014); Hammer (2014); Municipal Department 21 (2017), Author's own elaboration. 
administration, which divided the existing planning department into districts, and shifted from partial to full decision-making power in land procurement and planning management to public enterprises, such as the Vienna Land Procurement and Urban Renewal Fund (see Figure 3.1).

Process innovation involving non-institutional actors coincided with growing global awareness of sustainable urban development, especially after the Rio Declaration and Agenda 21 in 1992, which urged local governments to expand public participation in the local decision-making process. Despite strategic plans for implementing a Local Agenda 21 in the late 1990s, the institutional effort to create a citywide framework for localised grassroots participation never materialised under the Social-Democratic/Conservative coalition government. Unlike other European cities, for example in Sweden (Feichtinger and Pregernig, 2005) and the United Kingdom (Mittler, 2001), where the adoption of local agendas were organised in a top-down manner by local authorities, new opportunities for bottom-up mobilisation emerged in Vienna in 1998 through a further shift towards localised decision-making at the district level. Despite being rejected at the City level, the concrete interest in inclusion through bottom-up initiatives at the district level, in addition to assigning greater budget responsibility at the district level, initiated a pilot agenda process in the district of Alsergrund in 1998. The collaboration between this bottom-up initiative, Local Agenda 21 Alsergrund, and the district authorities, not only facilitated the active participation of local residents in neighbourhood planning, but also set new methodological standards for localised urban projects at the district level based on horizontal organisation of the planning process. Growing institutional recognition of the importance of community participation enabled citizens' initiatives to formulate planning concepts, as well as means to control and manage the process, together with the relevant municipal departments and private stakeholders. Such measures ultimately enabled citizens to influence the decision-making in the neighbourhood planning process (Novy and Hammer, 2007). This collaborative arrangement between citizens' initiatives, local residents and authorities became the City's organisational model for the Local Agenda 21 in 2002.

Another step towards localised collaborative arrangements emerged with the reorientation of the City's urban renewal strategies in the light of further decentralisation of public management under the same coalition government. Following the New Public Management precepts for output-oriented public services, the Urban Renewal Offices adopted a more active position in conflict management between 
different key stakeholders in urban redevelopment. Accordingly, two pilot renewal projects were carried out in the districts of Brigittenau and Leopoldstadt between 2000 and 2006, partially subsidised by the European Social Fund and the Regional Development Fund. In contrast to the City's local agenda process, the new collaboration between institutional and non-institutional actors in these renewal works was vertically managed, whereby co-management between different municipal bodies and public enterprises was prioritised over bottom-up residential participation. This mechanism was partly set up to meet the EU's funding criteria based on economic performance, rather than grassroots involvement. As such, the participation of communitybased initiatives in the planning process was limited. As a result, the role of local residents and the Urban Renewal Office remained consultative, whereas the decision-making authority in two urban renewal zones was expanded to the City's Economic Development Fund and the Municipal Department for European Affairs (Novy et al., 2010). As the renewal objectives largely focused on the economic development of neighbourhoods in decline, process innovation in these pilot projects drew on the flexibilisation of the City's renewal management structure, whereby the collaboration between key stakeholders at different territorial levels could occur beyond their institutional boundaries.

Despite limited innovation in bottom-up participation in urban renewal, the Urban Renewal Offices still remain the main coordinator of public dialogue between relevant institutional actors and residents in neighbourhood redevelopment, whereas the Local Agenda 21 Offices offer a bottom-up pathway for active participation in localised smallscale urban projects. Therefore, a mix of bottom-up and top-down participatory pathways in urban planning continue to characterise the collaborative arrangement between institutional and non-institutional actors in the overall institutional landscape of Vienna. However, the degree of recognition of local stakeholders and representation of their interests in the planning process is largely limited to the particular territorial level at which direct citizen participation in broader urban issues is continually constrained by its institutional design and the existing socioeconomic structure.

\section{The collaborative arrangement for active citizenship and its context}

Currently, coordination of bottom-up participatory processes at the neighbourhood level continues through the Local Agenda 21 and the Urban Renewal Offices. The former coordinates bottom-up pathways 
of active participation in neighbourhood planning, whereby citizens' initiatives formulate and manage planning concepts and methods that concern the sustainable development of their own district. More recently, a few efforts to overcome bureaucratic hurdles led to the implementation of new pathways for citizens' initiatives to directly participate in neighbourhood planning. In 2015, a new participatory program (Grätzeloase), initiated by the Local Agenda 21 Office and the city administration, was launched to activate citizen participation in co-production of non-market public spaces and communal activities at the district level. This involved two rounds of revision by the municipal departments, the district authorities, the police and the Chamber of Commerce. The emphasis on self-organisation in urban development at the local level is also visible in the growing number of Do-It-Yourself activities, such as urban gardening, food networks and repair activities, set forward by the Urban Renewal Offices (Jonas and Segert, 2019). Whilst continuing its primary function as the local coordination office for on-site conflict management in target planning areas, the Urban Renewal Offices have adopted a non-market-based 'commoning' approach to citizen participation, where extensive sharing and learning processes can be fostered within the public-citizens partnership in a non-hierarchical fashion. Accordingly, the trend towards self-organisation, based on a combination of bottom-up mobilisation and a top-down institutional framework, expanded across the city. Since January 2020, the Local Agenda process takes place in 11 out of 23 districts in Vienna.

The availability of bottom-up pathways to direct participation at the district level is determined by the respective district council, which is not only responsible for small-scale neighbourhood planning, but also decides whether to implement and finance $(50 \%)$ the Local Agenda process. Given this local anchor, incorporation of bottom-up initiatives in neighbourhood planning largely depends on the local political dynamics. The competition-based project selection method, especially in Grätzeloase, therefore, aimed at reshaping the political boundaries of self-organisation in urban development. Unlike the regular selection criteria of the Local Agenda 21 Office, any individual can submit community-oriented projects with a focus on public space revitalisation, which are then evaluated by a jury of relevant municipal departments. This 'commoning' approach to neighbourhood planning has expanded the alternative pathways for non-institutional actors to engage at the district level from 33 in 2015 to 83 in 2019.

The extent of local co-production in Grätzeloase, however, has been largely limited by its organisational model, which falls short of 
addressing the existing inequalities among neighbourhoods (Brait and Hammer, 2017). In addition to the competition-based selection method that diminishes the deliberative potential of the 'commoning' approach, a lack of appropriate public interventions to address the existing inequalities has led to the spatial concentration of self-organisation in neighbourhood planning (see Figure 3.2). In other words, participatory practices tend to be clustered in urban areas, where average earnings and educational attainment are relatively high compared to other districts, and participatory opportunities are already available. For example, an uneven spatial distribution of bottom-up urban initiatives is particularly visible in the district of Neubau (7th), with the second highest share of the population with tertiary education $(47.2 \%$ in 2017), and where most Grätzeloase projects have been initiated by the local businesses on large commercial streets. Whilst the local engagement of cultural and social associations is more frequent in the districts of Rudolfsheim-Fünfhaus (15th) and Hernals (17th), the local agenda groups take an active role in securing Grätzeloase projects in the districts of Joseftstadt (8th), Favoriten (10th), and Währing (18th), where bottom-up channels for participation are already available to citizens' initiatives by the districts' Agenda offices. A lack of both topdown and bottom-up pathways to participation is particularly visible in the district of Simmering (11th), governed by the FPÖ between 2015 and 2020, where (as of 2017) the share of the population with tertiary education (12.7\%) and the median income (20,568 EUR) are one of the lowest in the city (Statistics Vienna, 2020). The lack of an appropriate framework that could guide bottom-up practices in addressing the existing local inequalities has also engendered a low degree of thematic diversity. Whilst expanding opportunities for grassroots mobilisation enable citizens' initiatives to actively formulate and realise small-scale urban projects at the neighbourhood level, this contracting-out practice undermines horizontal networks of decision-making, in which the interests of different stakeholders are recognised and represented. As the city government retreats to a steering role in bottom-up participation of community-based initiatives, missing interactive mechanisms in direct participatory platforms has exacerbated event-based public-citizen collaboration, dominated by low-cost 'pop-up' urban projects, led by a limited number of civil society actors, which pay little attention to the place-specific contexts.

Whilst the capacity for bottom-up practices of co-production in neighbourhood planning lies at the district level, the localised planning system at the City level supplements the lack of participation opportunities in the districts, where the Local Agenda 21 is absent. Some 

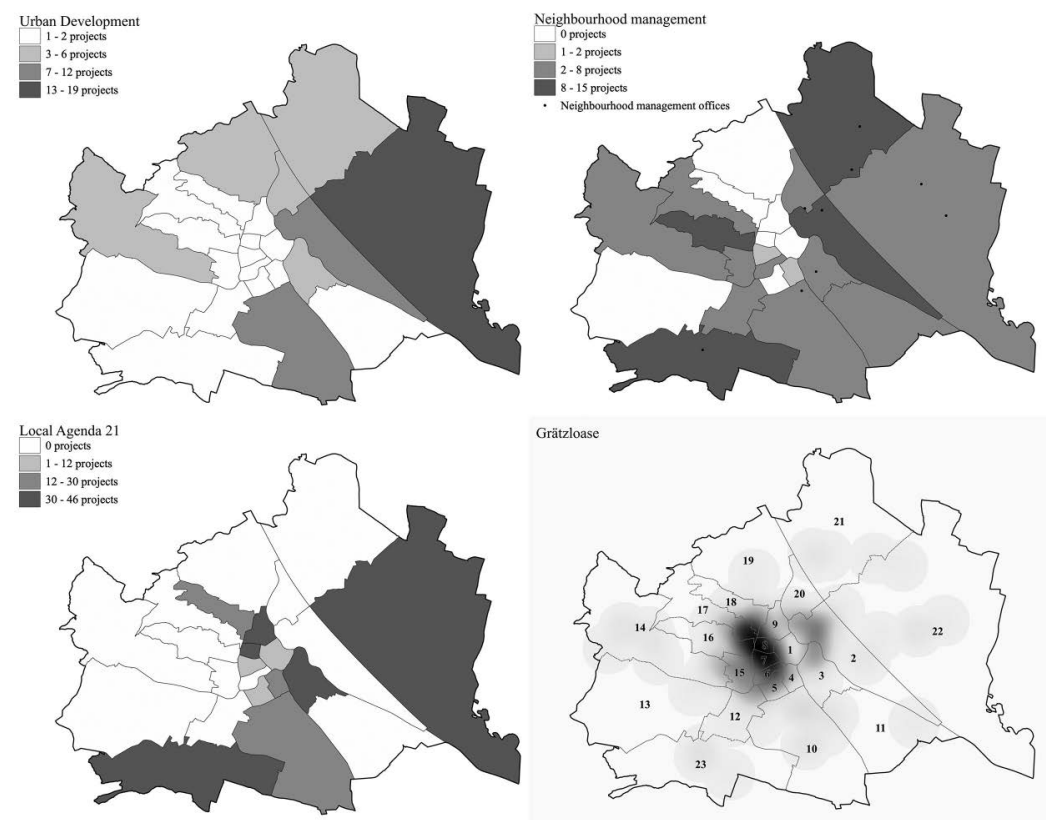

Figure 3.2 Geographical distribution of participatory channels in urban development in Vienna, 2020.

Source: Urban Renewal Office; Local Agenda 21, Author's own elaboration.

districts have particularly benefited from this institutional complementarity: namely, the underprivileged outer-city districts, such as Leopoldstadt (2nd), Ottakring (16th) and Floridsdorf (21st), where existing participatory channels are mostly organised by the local Urban Renewal Offices. Since 2012, the Urban Renewal Office expanded its role in new development areas, where the newly established Neighbourhood Management Offices coordinate participatory processes to accommodate the respective interests of old and new residents. Despite growing - and diversified - indirect participatory channels in localised urban projects, the extent of public-citizens partnership in new development areas is limited by the Vienna Building Code, which only grants direct control over the formal planning processes to property owners (see Figure 3.1). This is a distinct weakness in the City's participatory framework: its strong top-down orientation and its nearly exclusive role in urban planning results in limited citizen empowerment within the formal decision-making processes. Such a 
top-down and interventionist policy approach is an enduring legacy of the long Social-Democratic municipal government, which has provided limited support to civic involvement in public affairs. Whilst the Urban Renewal Offices and the Neighbourhood Management Offices provide local residents with opportunities for inclusion, engagement and deliberation in the planning processes, these participatory channels lack a policy framework to ensure that participation has a meaningful impact in policy implementation. Currently, there is no adequate policy framework to empower localised bottom-up practices in a diverse range of policy fields, other than urban planning, where local residents can make a substantial contribution to the outcome of the decision-making process beyond tokenistic participation.

\section{Conclusions}

In this chapter, we have shed light on the evolution of Vienna's urban development policy, and how the role of citizens in the localised planning system has changed throughout the period considered. From the early 1970s onwards, the City of Vienna has experimented with a diverse range of participatory tools, emerging from the decentralisation process, to encourage bottom-up mobilisation of community-based initiatives and the inclusion of non-institutional actors at different territorial levels of urban development. Whilst urban policies promoting citizen participation exist across cities and regions, the Vienna Model was particularly successful at linking non-institutional actors to the formal policy-making structure and limiting the potential interference of market actors. The longstanding decentralisation process downscaled substantial power and resources to public enterprises and district authorities, opening up top-down participatory pathways from 'informing' and 'consultation' to - limited degrees of - citizen power. Simultaneously, this rescaling process allowed both the city administration and its districts to enhance grassroots engagement at the neighbourhood level, allowing local residents to actively participate in designing and evaluating community planning projects. Whilst the opportunities grew, however, such standardisation and formalisation have compounded the bureaucratic obstacles to activate the participation of broader social groups. Some attempts have been made to circumvent this bureaucratic tendency. However, our analysis points out that the increased participation of organised community actors went hand in hand with negative side-effects of self-organisation in smallscale neighbourhood planning, resulting in the uneven distribution of participatory channels. 
The latter are mainly concentrated around the city's inner-city districts, where educational attainment and median earnings are relatively high. Our findings, therefore, echo some concerns raised by participation scholars: the literature in the field has warned about the potential self-selection of individuals with higher cultural, social and economic resources taking part in participatory initiatives (Fung, 2015). The uneven distribution of bottom-up initiatives across the city casts light on exclusionary processes engendered by participation policies in Vienna. This issue is mainly due to two factors, which may appear to be at odds with one another at face value. First, an over-regulation and bureaucratisation of participatory policy, which stifles citizens' engagement in planning. Second, the lack of a proper policy framework - if not political willingness - enshrining fully fledge participation. This policy deficit hinders meaningful involvement of citizens, falling short of empowering them. Therefore, the regulatory excess, coupled with the absence of a truly empowering participatory policy approach, seems to confirm the description of the Viennese municipal governance in the literature as a bureaucratic and top-down system. In turn, such a top-down approach fails to design interventions that reflect each neighbourhood's specific context. Ultimately, our analysis hints at increasing citizen participation in the planning process at different scales. The expansion of public participation, however, has been less successful in reducing unequal access to adequate representation for all and curbing the still strong intervention of the city administration. It appears that Vienna acts as a controlling enabler, reluctantly letting go of their exclusive oversight in the planning process. So far, we are yet to witness mechanisms that overcome participatory injustices emanating from Vienna's existing intraurban inequalities

\section{Note}

1 The construction of the conference complex around the United Nations was highly controversial in the 1980s, pushed by the SPÖ in the federal government, despite a failed legislative referral in 1981 and a popular initiative in 1982.

\section{References}

Antalovsky, E. and König, I., 1994. Planung initiativ: Bürgerbeteiligung in Wien. [pdf] Available at: https://bit.ly/3mLduQ2 [Accessed 14 April 2021]. Arnstein, S.R., 1969. A ladder of citizen participation. Journal of the American Institute of Planners, 35(4), pp. 216-224. 
Berger, H., 1984. Gebietserneuerung 1974-1984: Das Wiener Modell. [pdf] Available at: https://bit.ly/32aVh5f [Accessed 14 April 2021].

Brait, R. and Hammer, K., 2017. The Viennese Grätzloase: The role of the commons in countering market-based transformations of the city. Der Öffentliche Sektor - The Public Sector, 43(1), pp. 33-43.

Dangeschat, J.S. and Hamedinger, A., 2009. Planning culture in Austria: The case of Vienna, the unlike city. In: Knieling, J. and Othengrafen, F., eds., 2009. Planning cultures in Europe: Decoding cultural phenomena in urban and regional planning. Florence: Taylor and Francis, pp. 95-112.

Davies, J.S., 2004. Conjuncture or disjuncture? An institutionalist analysis of local regeneration partnerships in the UK. International Journal of Urban and Regional Research, 28(3), pp. 570-585.

Elwood, S., 2004. Partnerships and participation: Reconfiguring urban governance in different state contexts. Urban Geography, 25(8), pp. 755-770.

European Commission, 2014. Integrated Sustainable Urban Development. Cohesion Policy 2014-2020. [pdf] Available at: https://ec.europa.eu/ regional_policy/sources/docgener/informat/2014/urban_en.pdf

Feichtinger, J. and Pregernig, M., 2005. Imagined citizens and participation: Local Agenda 21 in two communities in Sweden and Austria. Local Environment, 10(3), pp. 229-242.

Feuerstein, C. and Fitz, A., 2009. Wann begann temporär? Frühe Stadtinterventionen und sanfte Stadterneuerung in Wien. Vienna: Springer-Verlag.

Förster, W., 1988. Stadterneuerung in Wien. In: Dase, M., Lüdtke, J. and Wollmann, H., eds., 1989. Stadterneuerung im Wandel: Erfahrungen aus Ost und West. Basel: Birkhäuser, pp. 103-114.

Fraser, N., 2010. Scales of justice: Reimagining political space in a globalizing world. New York: Columbia University Press.

Freisitzer, K. and Maurer, J., eds., 1985. Das Wiener Modell: Erfahrungen mit innovativer Stadtplanung. Empirische Befunde aus einem Großprojekt. Vienna: Compress.

Fung, A., 2015. Putting the public back into governance: The challenges of citizen participation and its future. Public Administration Review, 75(4), pp. 513-522.

Garcia, M., 2006. Citizenship practices and urban governance in European cities. Urban Studies, 43(4), pp. 745-765.

Goldfrank, B., 2007. The politics of deepening local democracy: Decentralization, party institutionalization, and participation. Comparative Politics, 39(2), pp. 147-168.

Hammer, K., 2014. BürgerInnenbeteiligung in der Stadt: Zwischen Demokratie und Ausgrenzung? Stadtpunkte, 9, Vienna. [pdf]Available at: https://wien.arbeiterkammer.at/service/studien/stadtpunkte/Stadtpunkte_9_.pdf

Jonas, M. and Segert, A. 2019. Repair Und Do-It-Yourself Urbanism in Wien aus Bezirksperspektive. [pdf] Available at: https://bit.ly/32aVfKw [Accessed 14 April 2021].

Kornberger, M., Meyer, R.E., Brandtner, C., et al., 2017. When bureaucracy meets the crowd: Studying "Open Government" in the Vienna City Administration. Organization Studies, 38(2), pp. 179-200. 
Mayerhofer, P. and Wolfmayr-Schnitzer, Y., 1996. Wiens "neue" Rolle im europäischen Städtenetz: Chancen als spezialisiertes Dienstleistungszentrum in Mitteleuropa? Wirtschaft und Gesellschaft, 22(4), pp. 515-551.

Mattl, S., 2000. Das 20. Jahrhundert. Geschichte Wiens. Vienna: Pichler Verlag.

Mittler, D., 2001. Hijacking sustainability? Planners and the promise and failure of local agenda 21. In: Layard, A., Davoudi, S. and Batty, S., eds., 2001. Planning for a sustainable future. London: Taylor \& Francis, pp. 53-60.

Municipal Department 21 - District Planning and Land Use, 2017. Masterplan Partizipative Stadtentwicklung: Frühzeitiges Beteiligen der Bevölkerung an städtebaulichen Planungs- und Widmungsprozessen. Werkstattbericht der Stadtentwicklung Wien, 172, Vienna. [pdf] Available at: https://www. wien.gv.at/stadtentwicklung/studien/pdf/b008505.pdf

Novy, A. and Hammer, E., 2007. Radical innovation in the era of liberal governance. European Urban and Regional Studies, 14(3), pp. 210-222.

Novy, A., Hammer, E. and Leubolt, B., 2010. The limits of 'controlled modernisation': The Grätzelmanagement experience in Vienna. In: Moulaert, F., Swyngedouw, E., Martinelli, F. and Gonzalez, S., eds., 2010. Can neighbourhoods save the city? Community development and social innovation. London: Routledge, pp. 185-197.

Novy, A., Redak, V., Jäger, J., et al., 2001. The end of Red Vienna. European Urban and Regional Studies, 8(2), pp. 131-144.

Pleschberger, W. and Mertens, C., 2012. Zur Parteipolitisierung Der Direkten Kommunalen Demokratie: Am Beispiel Der Großstadt Wien. Mitteilungen des Instituts für Deutsches und Internationales Parteienrecht und Parteienforschung, 18, pp. 24-35.

Schimak, G., 1993. Weltausstellung 1995 Wien. Budapest. Ursachen Und Konsequenzen Der Absage Wiens. In: Häußermann H., and Siebel W., eds., 1993. Festivalisierung Der Stadtpolitik. Stadtentwicklung Durch Große Projekte. Wiesbaden: Verlag für Sozialwissenschaften, pp. 108-133.

Statistics Vienna, 2020. Vienna in Figures. [pdf] Available at: https://bit. ly/3v2HASn [Accessed 14 April 2021].

Suitner, J., 2020. Vienna's planning history: Periodizing stable phases of regulating urban development, 1820-2020. Planning Perspectives, pp. 1-22. https://doi.org/10.1080/02665433.2020.1862700

Teaford, J.C., 2000. Urban renewal and its aftermath. Housing Policy Debate, 11(2), pp. 443-465.

Zhang, L., Lin, Y., Hooimeijer, P., et al., 2020. Heterogeneity of public participation in urban redevelopment in Chinese cities: Beijing versus Guangzhou. Urban Studies, 57(9), pp. 1903-1919. 